\title{
Analysis of Labor Planning on PT. Ganda Saribu Utama Binjai
}

\author{
Jonner Lumban Gaol ${ }^{1}$, Sarman Sinaga ${ }^{2}$, Lukman Nasution ${ }^{3}$ \\ ${ }^{1,2}$ Universitas Darma Agung Medan, Indonesia \\ ${ }^{3}$ Universitas Muslim Nusantara Al Washliyah Medan, Indonesia \\ jonnerlumbangaol99@gmail.com,sarmansinaga17@gmail.com,lukmanumnaw@gmail.com
}

\begin{abstract}
Considering the recruitment and selection process for the company is very important to support the success of the company in achieving goals. With selective recruitment and selection will provide value for the company. The quality of the company will also improve better with competent and qualified employees. The discussion in this study is to analyze the labor planning. The results of the analysis on PT. Ganda Saribu Utama Binjai in the implementation of labor planning at PT. Ganda Saribu Utama Binjai is carried out several steps, namely: Job analysis, receiving applicant data, analyzing cover letters that have been sent to the company, conducting new employee acceptance tests, interview calls, reference examinations, and granting decisions on the acceptance of prospective new employees. And there are some obstacles that become obstacles in the company in hiring employees, which among which there are prospective employees who are dishonest, there are prospective employees who are not in accordance with the company's standards, with some obstacles, the company does things that can overcome problems in employee recruitment, starting with the implementation of selection in accordance with company procedures, and making specification adjustments in accordance with company standards.
\end{abstract}

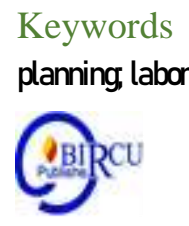

\section{Introduction}

Labor planning in a company is an important aspect of the company's management in carrying out its corporate activities. Incorrect labor planning will affect the costs incurred and will have a further impact on the company's work productivity.

This is because labor is the most important asset in an organization or company. Labor or can also be called manpower a term that refers to the aspect of strength that exists in each workforce to be able to carry out its duties, able to do creative and innovation to develop its work so as to keep pace with the growth, development, globalization, and demands of service tasks and productivity of the organization therefore in many literature discussions of labor can not be separated with the theme of empowerment of labor itself.

Workforce planning is substantially a process that aims to provide "strong" human resources or in accordance with the needs either in numbers, qualifications, and timings or Labor planning can also be interpreted as a process to establish strategies to acquire, utilize, develop and maintain the workforce in accordance with the needs of the present company and its development in the future. Therefore labor planning will not be separated from the process of analysis and identification of needs.

Likewise, this is very noteworthy by PT. Ganda Saribu Utama Binjai which is the main object in this research. Pt. Ganda Saribu Utama Binjai itself is a manufacturer of household appliances, especially kitchen utensils made of metal to plastic with domestic and export markets. 
Nowadays, the company desperately needs employees who have the power of innovation and creative quality, so that the recruitment and selection process for new employees is very strict.

\section{Review of Literatures}

Managing the Human resources is challenging for every organization. To effectively use the latent competencies and skills of employees has always been the ultimate task for HR managers. Measuring its attributes and performance is the crucial part of the HR department. These ultimate tasks can now be solved with the help of new IT based technology like HR or Workforce Analytics which helps to transform the raw data into insightful and quantifiable results. With the help of HR analytics various workforce planning can be made in a more strategic approach. This helps the organization to have an upper hand over its competitors, as human resources have always been the vital aspect of every organization. Workforce Analytics is can be defined as an evidence based approach that contains the elements of business intelligence, tools and methods ranging from simple reporting of HR matrics to the predictive model. The purpose of HR analytics is to enable the organizations to make better strategic decisions on the people side of the business. HR analytics can also be defined as the analytics which helps in the data constructing a storyline. It is mining the primary raw data for useful information ultimately relating the storyline to overall business goal. HR analytics processes the raw data and then tries to point out the various troubled metrics of HR and highlights the critical area to work upon which helps in making important strategic decisions for the top managemet (Momin and Mishra, 2015).

Workforce planning presents the basis for a systematic technique to assessing the number and kind of individuals needed through an institution and guaranteeing that people considerations are taken under consideration in business plans. Having bought knowledge on the supply of persons, and from environmental scanning, it leads to the education of recruitment, retention, administration succession and ability management plans (Leung, 2015). It is essential for the reason that it encourages employers to improve clear and specific links between their trade and HR plans and to integrate the two extra readily. It makes it possible for better manipulate over staffing fees and numbers employed, and it allows employers to make more instructed judgements about the expertise mix of their firms. Research conducted with the aid of the Institute for Employment reviews writer of (Reilly, 1999) established that there have been three foremost motives why organizations engaged in personnel planning: 1. Planning for substantive reasons, that is, to have a practical effect by optimizing the use of resources and/or making them more flexible, acquiring and nurturing skills that take time to develop, identifying potential problems and minimizing the chances of making a bad decision. 2. Planning because of the process benefits, which involves understanding the present in order to confront the future, challenging assumptions and liberating thinking, making explicit decisions that can later be challenged, standing back and providing an overview and ensuring that long-term thinking is not driven out by short-term focus. 3. Planning for organizational reasons, which involves communicating plans so as to obtain support/adherence to them, linking HR plans to business plans so as to influence them, (re)gaining corporate control over (Damnjanović, 2016).

The globalization that has swept the world has influenced the development of various sectors of activities in Indonesia. Competition in a very tight working world exposes organizations to strong efficiency and competitiveness.To improve efficiency, among 
others required Human Resources (HR) quality. The most important resource in an organization is the human resources, the people who provide the energy, talents, creativity and their efforts to the organization for an organization to survive its existence (Ningsih, 2018).

\section{Research Methods}

This research was conducted at PT. Ganda Saribu Utama located at Jalan Raya Medan - Binjai Km 12.5 No.33 Medan, North Sumatra. This research was conducted because researchers wanted to review the recruitment process, selection and placement of employee labor.

The source for the analysis is an HRD (Human) at PT. Ganda Saribu Utama Binjai, which runs employee recruitment at the company. The type of data in this study is primary data, namely data obtained from informants at the time of interview between researchers and informants using research instruments, namely by asking a number of open questions. The data taken is in the form of interview results of examiners on HRD at PT. Ganda Saribu Utama Binjai.

This research uses qualitative approach, which the next assessment in this research is a research procedure that produces descriptive data in the form of written or oral words. Descriptive analysis is a way of formulating and interpreting existing data, thus providing a clear picture of the data studied. The respondents in conducting this research are the human resources management section, namely HRD (Human Resources Departement.

\section{Results and Discussion}

\subsection{Implementation of Recruitment process and Selection of Applicants at PT. Ganda Saribu Utama Binjai}

From what the author has observed and done to the interviewer, as for the interview results from the respondents recruitment and selection (HRD) as follows:

1. Labor planning is carried out because of employees who leave the company and because of the needs of more employees in accordance with the quota of prospective employees to be recruited and selected

2. Labor planning is carried out because of the addition of work tools in the form of machines and construction is carried out for the creation of work space, which is done in order to complete the task more efficiently and effectively.

\subsection{Obstacles in the Recruitment and Selection Process of PT Employees. Ganda} Saribu Utama Binjai

Obstacles that often arise in pt. Ganda Saribu Utama Binjai include:

1. Attitudes of prospective new employees who are less honest and not open Attitudes of prospective new employees who are less open and honest in providing answers to questions when interviewed by recruitment officers should be more considered in detail. When interviewing the answer to the question should pay attention in detail to the way he speaks, his dress, his body movements and his attitude of speaking. Dishonest and less open new employees will hinder the process. If there is no honesty and openness then the process of manufacturing will be. 2. Difficulty finding prospective employees who are in accordance with the field required by the company In the recruitment and selection process the biggest difficulty is finding a match between prospective new employees and the fields needed within the company. 
2. Difficulty in determining the standard size of qualification of prospective new employees, lack of suitability of qualifications submitted to the company by applicants resulting in the strandar qualification can not be in accordance with what is expected by the company. Sometimes many only see the value of Compulsive Achievement Index (GPA) that will appear obstacles that are not in accordance with his work. Applicants who have a high GPA score are not necessarily able to work well in accordance with the company's expectations. Most people who are good at theory or lessons are not necessarily good at work in the real world of work. Usually most people only look at the results of their GPA and most of the applicants we receive sometimes do not match the quality of the value. His job is sometimes worse even though the employee has a high GPA, so applicants who have a high GPA also do not necessarily have quality performance." The exposure of the interview above can be concluded that most recruits view the index value of compulsive achievement as the standard of qualifications of job applicants. Value as a measuring point in recruiting and selecting employees.

\subsection{How to Overcome Obstacles in the Recruitment and Selection Process}

In overcoming the obstacles that exist during the recruitment and selection process of prospective new employees is needed efforts and solutions to solve the problem, so that in the future it is expected to run the recruitment and selection process of employees in accordance with the expectations of the company in PT. Ganda Saribu Utama Binjai. The following efforts and efforts have been made to overcome the obstacles that arise:

1. Examination of applicant reference data is more basic To know how the openness and honesty of the reasoning, it is necessary to conduct a more detailed examination of applicant reference.

2. Efforts to overcome obstacles in finding new candidates karywan in accordance with their fields, the obstacles of this company are very difficult to overcome because of the many fields that exist but usually only certain fields that are only needed by the company.

\section{Conclusion}

Based on the data that has been written by the author in analyzing labor planning at PT. Ganda Saribu Utama Binjai, which after observation and interview about recruitment and selection of employees can be concluded as follows:

1. The success of a company can not be separated from the role of human resources that have good quality. To achieve the company's objectives, the company must also be strict in the selection or recruitment of employees who will work in the company. Qualified employees will affect the quality of the company as well. Peoses recruitment and selection of employees must be in accordance with procedures and selective in the selection of prospective employees.

2. In the implementation of employee recruitment at PT. Ganda Saribu Utama Binjai is carried out several steps as follows:

a. Analysis of jobs that require new employees

b. Receive data of applicants who send a job application letter to the company

c. Analyze the cover letter that has been sent to the company. 


\section{References}

Ardana, I Komang dan Mujiati, Ni Wayan. 2012. Manajemen Sumber Daya Manusia. Yogyakarta: Graha ilmu.

Damnjanović, A., et al. (2016). Management Of The Workforce And Business Planning. Conference: International Conference "Economics and Management-Based on New Technologies"At: Vrnjačka BanjaVolume: 6

Darmawati. 2017. Analisis Perekrutan dan Seleksi Tenaga Kerja pada PT. Borwita Prima Kendari. Skripsi. Fakultas Ekonomi dan Bisnis, Universitas Halu Oleo Kendari

Dessler, Gary. 2012. Human Resource Management. New Jersey : John Willey and Sons.

Dolip, Anita Sari. 2012. Analisis Pelaksanaan Rekrutmen, Seleksi dan Penempatan Tenaga Kerja Pada BMT UGT Sidogiri Pasuruan. Skripsi. Fakultas Ekonomi Universitas Islam Negeri Maulana Malik Ibrahim Malang

Handoko, T. Tani. 2011. Manajemen Personalia Sumber Daya Manusia. Edisi II. Yogyakarta: BPFE

Hasibuan, Malayu S.P. 2013. Manajemen Sumber Daya Manusia, PT. Bumi Aksara, Jakarta.

Ichsan, R. N., Suparmin, S., Yusuf, M., Ismal, R., \& Sitompul, S. (2021). Determinant of Sharia Bank's Financial Performance during the Covid-19 Pandemic. Budapest International Research and Critics Institute (BIRCI-Journal): Humanities and Social Sciences, 4(1), 298-309.

Ichsan, Reza Nurul; SE, M. M. Bahan Ajar Manajemen Sumber Daya Manusia (MSDM). CV. Sentosa Deli Mandiri

Ichsan, R., \& Nasution, L. (2021). Sosialisasi Pelatihan Disiplin Kerja Karyawan Restaurant Kenanga Garden Medan. PKM Maju UDA, 1(3), 127-132. doi:10.46930/pkmmajuuda.v1i3.885

Leung, P. P. L., Wu, C. H., Ho, G. T. S., Ip, W. H., \& Mou, W. L. (2015). Workforce modelling, analysis and planning: A feasibility study in a local nursing home. In 2015 IEEE International Conference on Industrial Engineering and Engineering Management (IEEM) (Vol. 2016-Janua, pp. 1337-1341). IEEE.

Mangkunegara, Anwar Prabu. 2012. Manajemen Sumber Daya Manusia Perusahaan. Bandung : PT Remaja Rosdakarya.

Mathis, Robert L dan John H. Jackson, 2012. Manajemen Sumber Daya Manusia. Buku 1, Alih Bahasa: Jimmy Sadeli dan Bayu. Prawira Hie, Salemba Empat. Jakarta.

Mohammad Yusuf, \& Reza Nurul Ichsan. (2021). Analysis of Banking Performance in The Aftermath of The Merger of Bank Syariah Indonesia in Covid 19. International Journal of Science, Technology \& Management, 2(2), 472-478. https://doi.org/10.46729/ijstm.v2i2.182

Momin, W.Y.M., and Mishra, K. (2015). HR Analytics as a Strategic Workforce Planning. International Journal of Applied Research 2015; 1(4): 258-260.

Nawawi, 2012. Manajemen Sumber Daya Manusia: Untuk Bisnis Yang Kompetitif. Yogyakarta: Gajahmada University Press

Nasution, L., \& Nurul Ichsan, R. (2021). Pengaruh Penerapan Kepemimpinan Terhadap Kinerja Pegawai Pada Kantor Dinas Pendidikan Kabupaten Karo. Jurnal Ilmiah METADATA, 3(1), 308-320. Retrieved from http://ejournal.steitholabulilmi.ac.id/index.php/metadata/article/view/59

Nurul Ichsan, R., \& Lumban Gaol, J. (2021). Pengaruh Kepemimpinan Terhadap Disiplin Kerja Pegawai Pada Kantor Dinas Pendidikan Kabupaten Karo . Jurnal Ilmiah 
METADATA, 3(1), 344-355. $\quad$ Retrieved from http://ejournal.steitholabulilmi.ac.id/index.php/metadata/article/view/62

Nasution, L., \& Ichsan, R. (2021). Sosialisasi Peluang Usaha Bank Sampah Dalam Peningkatan Pendapatan Masyarakat Di Masa Covid 19. PKM Maju UDA, 1(3), 107-112. doi:10.46930/pkmmajuuda.v1i3.882

Nitisemito, Alex. 2014. Manajemen Personalia. Jakarta: Penerbit Ghalia Indonesia.

Ningsih, S. (2018). The Relationship Between Motivation and Worker's Productivity in Civil Registration and Population Department, Asahan Regency, Indonesia. Budapest International Research and Critics Institute-Journal (BIRCI-Journal). P. 148-160.

Pusparani, Devira. 2018. Analisis Proses Pelaksanaan Rekrutmen, Seleksi, dan Penempatan Kerja Karyawan (Studi pada Hotel dan Restoran Mahkota Plengkung Banyuwangi). Jurnal Administrasi Bisnis (JAB)|Vol. 58 No. 2 Mei 2018

Reilly, P (1999) The Human Resource Planning Audit, Cambridge, Cambridge Strategy Publications.

Rivai, Veithzal dan Sagala, Ella Jauvani. 2012. Manajemen Sumber Daya Manusia Untuk Perusahaan : Dari Perusahaan Ke Praktik, Edisi ke-1, Rajawali Pers, Jakarta.

Siagian, Sondang. P. 2014. Manajemen Sumber Daya Manusia. Jakarta:BumiAksara

Simamora, Henry. 2012. Manajemen Sumber Daya Manusia. Edisi 1. Yogyakarta: STIE YKPN Yogyakarta.

Siswanto, Bejo. 2012. Manajemen Tenaga Kerja Indonesia:Pendekatan Administratif dan Operasional. Jakarta Bumi: Aksara.

Sedarmayanti, 2012. Manajemen Sumber Daya Manusia. Jakarta : Refika Aditama Eresco. Sugiyono. 2011. Metode Penelitian Bisnis. Bandung: Alfabeta.

Sutrisno, Edy. 2015. Manajemen Sumber Daya Manusia(Cetakan ke tujuh).Jakarta: Kencana Prenada Media Group

Yusuf, M., Ichsan, R., \& Saparuddin, S. (2021). Determinasi Investasi Dan Pasar Modal Syariah Terhadap Pertumbuhan Ekonomi Di Indonesia. JEpa, 6(1), 397-401. Retrieved from http://jurnal.pancabudi.ac.id/index.php/jepa/article/view/1121 